Available online: https://journals.researchsynergypress.com/index.php/ijebce/

International Journal of Entrepreneurship, Business and Creative Economy (IJEBCE)

ISSN 2775-3085 (Online) | 2775-3107 (Print)

Volume 1 Number 2 (2021): 54-64

\title{
Comparison of Hub and Home Mode Learning: An Action Research from Philippines
}

\author{
Arnel G. Perez ${ }^{1}$ \\ ${ }^{1}$ Mabalacat City College, Philippines
}

\begin{abstract}
Recent studies underscored the different actions of the Higher Educational Institutions (HEI's) all over the world in securing the health of the students as well as the academic personnel, and likewise in mitigating the spread of coronavirus or COVID-19. Most of HEI's closed the schools in March 2020 and shifted their paradigm from face-to-face to distance or remote learning. Mabalacat City College (MCC) as one of the HEI's in the Philippines resolved this concern through its innovative flexible learning. In the flexible learning of MCC, the students were given options to choose between the Hub mode (modular type) and Home mode (online class). The respondents in this action research were 310 students enrolled in the course "The Life and Works of Rizal", wherein the $230(74.19 \%)$ of the respondents were from the Home mode of learning and the $80(25.81 \%)$ of the respondents were from the Hub mode of learning. The finding in this study confirmed that the students in the Home mode of learning surpassed the performance of the students who were in Hub mode of learning.
\end{abstract}

Keywords: Higher Education Institutions; COVID-19; Mabalacat City College; Home and Hub mode; Flexible learning

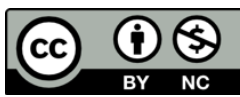

This is an open access article under the CC-BY-NC license.

\section{INTRODUCTION}

The COVID-19 pandemic was announced by World Health Organization (WHO) in March 2020 (WHO, 2020). As response to mitigate the spread of the coronavirus, most Asian countries declared lockdown on March 16, 2020 (Balakrishnan, 2020; Bozkurt et al., 2020), and shifted their paradigm from face-to-face to distance learning or remote learning to secure the health of the students as well as the teachers (Almazova et al., 2020; Balakrishnan, 2020; Bozkurt et al., 2020; Ghazi-Saidi et al., 2020; Goncalves, 2020; Habaragoda, 2020; Karademir et al., 2020; Mukherjee \& Hasan, 2020; \& Refaat El Said, 2020). The Philippines as one of the Southeast Asian countries recorded its first COVID-19 cases on March 6, 2020, and to mitigate the spread of the COVID-19, the Philippine government suspended the classes at all levels in the National Capital Region on March 9, 2020 and later extended the suspension of classes in entire island of Luzon by declaring Enhanced Community Quarantine (ECQ) or lockdown until April 14, 2020 (Bozkurt et al., 2020).

As response to global COVID-19 pandemic, the Department of Education (DepEd) and Commission on Higher Education (CHED) decided to move the school opening to August 2020 and implemented remote or distance learning (Bozkurt et al., 2020). The DepEd launched its DepEd Commons, an online learning platform where students and teachers can freely access their educational learning resources and materials (DepEd Commons, 2020). The Commission on Higher Education (CHED) in support to Republic Act No.11494 or "Bayanihan to Recover as One Act" (Congress of the Philippines, 2020) released the CHED Memorandum Order No. 04, Series of 2020 
International Journal of Entrepreneurship, Business and Creative Economy (IJEBCE), Vol. 1 (2), 54-64 Comparison of Hub and Home Mode Learning: An Action Research from Philippines

Arnel G. Perez

under the Resolution No. 412-2020, Series of 2020 which required the public and private Higher Educational Institutions (HEIs) to utilize flexible learning (CMO No. 4, Series of 2020: Commission on Higher Education, 2020).

At the onset of the quarantine, the Higher Education Institutions (HEI's) in Pampanga were challenged on the demands of the new normal; and to cope with the situation, new mode of learning such as flexible learning was required by Commission on Higher Education (CMO No. 4, Series of 2020: Commission on Higher Education, 2020). Mabalacat City College (MCC), as one of the HEI's in Pampanga responded to thedemands of the new normal and her immediate action was to place Hubs on the different barangays of Mabalacat City. These Hubs serve as the working stations for the modules where the students can claim and submit their respective modules. The purpose of setting the Hubs at the different barangays is to ease the burden of commuting and likewise to respond on the protocols of Inter-Agency Task Force (IATF) of the Philippines, which imposed Stringent Social Distancing Measures (Omnibus Guidelines on the Implementation of Community Quarantine in the Philippines, 2021; Republic of the Philippines Department of Health, 2021).

In the process, the modes of learning at MCC became flexible because the students were given options to choose between the Hub mode (modular type) and Home mode (online class). This action made by the Mabalacat City College (MCC), was likewise her response to support the "Bayanihan to Heal as One Act" of the Commission on Higher Education under Resolution No.412-2020, series of 2020 which required all public and private Higher Education Institutions (HEIs) in the Philippines to utilize flexible learning mode (CMO No. 4, Series of 2020: Commission on Higher Education, 2020). Moreover, MCC's flexible learning (Hub and Home mode of learning) was likewise a response to UNESCO Sustainable Development Goal 4 (SDG 4) of the 2030 Agenda that aims to "ensure inclusive and equitable quality education and promote lifelong learning opportunities for all" (UNESCO, 2017).

This paper presents the implications of the flexible modes of learning of MCC. As mentioned, MCC's response to the demands of the new normal is reflected on its modes of learning which is composed of the Hub mode and Home mode of learning. In the Hub mode, the students accomplish their academic requirements (worksheets) by claiming their modules, as well as the worksheets, from the respective Hubs of the barangays, where they would also return them. On the other hand, in the Home mode of learning, the students secure and submit their worksheets at the Edmodo and they attend their online discussion at least three hours per week. Edomodo itself is a Learning Management System (LMS) platform. Hence, the paper determines if there are significant differences on the academic performances of the students who are into Hub and Home modes of learning.

\section{LITERATURE REVIEW}

The global lockdown occurred in the month of March 2020 (WHO, 2020), and Asian countries like Indonesia, Malaysia, Philippines, Singapore, Thailand, and others likewise declared lockdown to prohibit the spread of COVID-19 (Diplomat Risk Intelligence, 2020). However, the lockdown or quarantine drastically impacted the economy, healthcare professional, education, sports, and even the spiritual practices of the world (Kouser, Kausar, \& Ghani, 2020; Hur \& Fenuwine, 2020; Ornell, Schuch, Sordi, \& Kessler, 2020). As regards to academic community, the educational institutions throughout the world due to the Covid-19 pandemic shifted their paradigm from face-to-face to distance learning or remote learning (Balakrishnan, 2020; Ghazi-Saidi et al., 2020; Habaragoda, 2020; Mukherjee \& Hasan, 2020; \& Refaat El Said, 2020).

Balakrishnan (2020) explored the educational responses to the Covid-19 pandemic in the national educational systems of Indonesia, Malaysia, Singapore and Thailand. The study included the date of the physical closure of the institutions and their immediate action to address the needs. As found out: Indonesia closed the schools on March 16, 2020 and immediately implemented distance learning curriculum and made the lessons available via online and television broadcast; 
International Journal of Entrepreneurship, Business and Creative Economy (IJEBCE), Vol. 1 (2), 54-64 Comparison of Hub and Home Mode Learning: An Action Research from Philippines

Arnel G. Perez

Malaysia closed also its schools on March 16, 2020 and the Ministry of Education utilized the social media platforms (Twitter and Facebook) to disseminate information to the teachers, parents and students. Similarly, the minister designed multiple infographics to access the online learning; Singapore closed its schools on April 8, 2020 and implemented blended learning scheme (alternate between home-based learning and in-person classes), and offered online learning for the disadvantaged children; and Thailand also closed its schools on March 16, 2020 and immediately resorted to distance learning television (DLTV) model nationwide and to various online platforms. Hence, Indonesia, Malaysia, Singapore and Thailand resorted to distance learning and the utilization of social media platforms to continuously deliver education to the children and youth without risking their health and well-being.

As early as February 27, 2020 before the announcement of global lockdown in March 2020, the Japanese government announced the physical closure of the schools. The immediate closure of the schools assumed to re-open at the end of March, but on April 7, 2020, the state of emergency declared to extend the school closing beyond May 6, and the government considered to start the introduction of school year in September rather than April. Hence, during the school closing in Japan, most schools offered alternative leaning supplementals such as self-learning support (sending print materials via email and pre-recorded video lectures shared on YouTube or online platforms), and some schools provided synchronous interactive sessions via Zoom and other synchronous communication tool with digitized materialsto boost students' motivation in engaging in remote learning (Bozkurt et al., 2020).

In the Philippines, the Commission on Higher Education (CHED) in support to Republic Act No. 11494 or "Bayanihan to Recover As One Act" (Congress of the Philippines, 2020) released the CHED Memorandum Order No. 04, Series of 2020 under the Resolution No. 412-2020, Series of 2020 which required the public and private Higher Educational Institutions (HEIs) to utilize flexible learning that included complementing outcome-based education approach (employing various means of delivery and assessment); providing mechanism to inform and orient the learners on the learning management system; establishing means for students and teacher engagement (utilizing the electronic media for communication); maximization of the use of technology to support learning and teaching; implementing grants or support capacity-building programs for the administration, faculty and staff; and prioritizing the health and safety protocols (CMO No. 4, Series of 2020: Commission on Higher Education, 2020).

In developing country like Sri Lanka as mentioned by Habaragoda (2020), complete online degree programs or courses were not common or popular, the primary based of the educational institutions were on face-to-face traditional learning environment. However, due to Covid-19 pandemic, Sri Lankan universities shifted their mode of teaching to online platforms via Learning Management System (LMS). But the greatest challenge encountered by the Sri Lankan universities if the students have equal access to continue their education on the online or digital space. Hence, the response of the Sri Lankan government introduced a loan scheme that provided financial support for students to purchase laptop or computer. Moreover, the challenge of the Sri Lankan universities did not end on providing laptop or computer to the students but the study revealed that the instructors as well as the learners found difficulties in adopting to technology driven pedagogical approach due to lack of proper professional training. In like manner, another significant challenge in Sri Lanka were the lack of access to electricity and the poor IT infrastructure in the remote areas.

In Egypt as cited by Refaat El Said (2020), the survey affirmed that majority of the educational leaders endorsed online distant learning in higher education, and likewise, found that the most prominent difficulties of distance education were internet connectivity and weak IT skills. Similarly, the surveys found that recorded lectures were the most plausible way to deliver educational materials. However, the recommendations of the nation-wide surveys influenced the government of Egypt to resort to integrate fac-to-face with online learning (merging on-campus and online distant learning) in all future higher education plans. 
International Journal of Entrepreneurship, Business and Creative Economy (IJEBCE), Vol. 1 (2), 54-64 Comparison of Hub and Home Mode Learning: An Action Research from Philippines

Arnel G. Perez

In the study conducted by Goncalves (2020), the schools in Portugal closed on March 16, 2020 as response to the global pandemic due to Covid-19, and the impact of the school closure resulted to 2 million students in the basic education stayed at home with no face-to-face lecture. Moreover, the National Union of Higher Education (NUHE) of Portugal announced to implement distance learning and to adapt online teaching (either merely recording or transmitting online lecture), and likewise, the Ministry of Education published the Guiding Principles for the Implementation of Distance Learning in Schools on March 27, 2020. In this study, some lapses like failure to produce guidelines for the implementation of the distance learning by the Ministry of Science and Higher Education were found. Similarly, the Minister of Education overlooked the numbers of the students without internet connection in its new distance learning plan. Thus, it has been concluded in this study that the preparedness of Portugal about distance learning was immature because of lack equipment and skill resources.

Karademir et al. (2020) mentioned that Turkey's distance learning or online learning response to COVID-19 pandemic was not sufficient to maintain the quality of education. In the study, they revealed that the implementation of distance education in Turkey suffered from infrastructural and psychological issues. As regard to infrastructural, the universities' learning management systems were not sufficient to accommodate distance learning, and in this connection, not all students afford to attend online learning. In terms of psychological issue, anxiety and stress were encountered due to pandemic and the uncertainties involved in the distance education process. Hence, Turkey's readiness to distance education was likewise premature like the other countries who were not previously practiced distance learning.

The lockdown for students and teachers in Russia was implemented on March 23, 2020. The delayed of the closure of physical education was due to varying reasons such as lack of necessary equipment at home, use of work computers and other office equipment, necessary documents, holding face-to-face meetings and meetings to agree on distance work, and the prevailing state of mind that digital technologies and tools were insufficient to educate individual (Bozkurt et al., 2020). However, as mentioned by Almazova et al. (2020) even E-learning was normally conducted in Russia as stipulated in 2018 Decree of the President of the Russian Federation No. 204, creating modern educational environment by 2024, the implementation of online learning in Russian higher education challenged the university teachers pertaining to computer literacy level and electronic environment and support. Similarly, the higher educational system in Russia faced a great challenge because of the lack of readiness of the academic staff as well as the students. Hence, to attain efficient online education, the Russian higher education should increase the level of technology and methodological readiness of the university teachers for online teaching and learning.

As response to the global COVID-19 pandemic, all educational institutions in South Africa was closed on March 18, 2020, and to continue the academic year 2020, the Department of Basic Education (DBE) implemented a curriculum recovery plan. In the curriculum recovery plan, the opening of classes was moved to June (from the usual January), and all safety protocols implemented by the National State of Disaster (NSD) due to COVID-19 were observed. However, the response of the Department of Basic Education through curriculum recovery program in South Africa to mitigate the spread of COVID-19 was not fully compliant to the safety protocols implemented by the NSD as revealed in the study (Litshani et al., 2020).

In this new normal due to the global COVID-19 pandemic, the term "emergency remote education" was used to describe the mass changes brought about by COVID-19 and the other similar crises, to contextualize the activities that arise out of necessity and with necessary haste (Bozkurt et al., 2020). Most of the Asian countries like Indonesia, India, Malaysia, Philippines, Russia and Thailand declared lockdown in March 2020 after the announcement of the WHO about the COVID-19 pandemic. Most of the schools around the world closed in March 2020 and modified their curriculum, and shifted their paradigm from face-to-face to remote or distance learning, to synchronous and asynchronous, to flexible learning, and modular mode of learning. The 
International Journal of Entrepreneurship, Business and Creative Economy (IJEBCE), Vol. 1 (2), 54-64 Comparison of Hub and Home Mode Learning: An Action Research from Philippines

Arnel G. Perez

implementation of online learning or remote learning challenged all academic institutions specific to readiness of the students as well as the teachers; availability of online resources such as computer, laptop, cellphone, and internet; and in using Learning Management Systems.

\section{Statement of the Problem}

This action research presents the implications of the flexible modes of learning of MCC. As mentioned, MCC's response to the demands of the new normal is reflected on its modes of learning which is composed of the Hub mode and Home mode of learning. Hence, the study likewise seeks to answer the following:

1. How may the students' submission of worksheets be described in term of the following:

- Complete submission;

- Lacking in submission; and

- No submission of worksheet

2. What are the percentage of the incomplete grades in both modes of learning?

3. Are there significant differences on the academic performance of the students who are in Hub mode and Home mode of learning?

4. What are the implications of the findings in this action research? And what action/plan can be proposed to address the implications?

\section{RESEARCH METHOD \\ Research Design}

The purpose of this action research was to determine the implication of the flexible learning modes of MCC. This include the description of the submission of worksheets such ascomplete submission; lacking in submission; no submission of worksheet; and likewise, the number of incomplete grades. In like manner, the study determined the significant differences on the academic performances of the students who attended the Hub and Home modes of learning. Hence, the study utilized the descriptive research design in describing the variables. The purpose of descriptive research was to describe systematically and accurately the facts and characteristics of a given population or area of interest; and likewise, to discover associations or relationships between or among selected variables (Kothari, 2004).

\section{Participants}

The selected samples are bona fide students at the MCC who took the course, "The Life and Works of Rizal" during the first semester of the academic year 2020-2021. There are 310 students officially enrolled on the said course, wherein the $230(74.19 \%)$ of the students are from the Home mode of learning and the $80(25.81 \%)$ of the students are from the Hub mode of learning.

\section{FINDINGS AND DISCUSSION}

As previously mentioned, MCC's immediate action to the new normal brought by the COVID-19 pandemic, was to implement flexible learning which was both inclusive and non-discriminatory. Magsambol (2020) cited that CHED's flexible learning involved combination of digital and nondigital technology which aimed to ensure the continuity of inclusive and accessible education. MCC's flexible learning was designed to serve all the students in the community that advocated both inclusivity (UNESCO, 2017) and accessibility (CMO No. 4, Series of 2020: CHED, 2020). In the flexible learning of MCC, the students were given options to choose between the Hub mode (modular type) and Home mode (online class). In the Hub mode, the students accomplish their academic requirements (worksheets) by claiming their modules, as well as the worksheets, from the respective Hubs of the barangays, where they would also return them. Whereas, students in the Home mode secure and submit their worksheets at the Edmodo and theyattend their online 
International Journal of Entrepreneurship, Business and Creative Economy (IJEBCE), Vol. 1 (2), 54-64 Comparison of Hub and Home Mode Learning: An Action Research from Philippines

Arnel G. Perez

discussion at least three hours per day. Hence, this action research determined the implication of the flexible learning of MCC.

The respondents in this action research were 310 students enrolled in the course "The Life and Works of Rizal", wherein the 230 (74.19\%) of the respondents were from the Home mode of learning and the $80(25.81 \%)$ of the respondents were from the Hub mode of learning. As reflected by the data in Table 1, 114 (49.56\%) of the students who were in the Home mode completed their worksheets (complete submission), 108 (46.95\%) of the students were lacking in submission of worksheets (lacking in submission), 8 (3.48\%) of the students did not return their worksheets (no submission), and $24(10.43 \%)$ of the students obtained incomplete grades (INC). Whereas for the students who were on the Hub mode of learning, $26(32.50 \%)$ of them completed their worksheets, $49(61.25 \%)$ of the students were lacking submission of worksheets, $5(6.25 \%)$ of the students did not return their worksheets, and $15(18.75 \%)$ of the students obtained incomplete grades. Hence, in terms of submission of the requirements, the obtained data indicated that the respondents who were into Home mode of learning, academically perform well as compared to the respondents who were into Hub mode of learning.

Moreover, the finding particularly to the respondents in the home mode or online learning can be attributed their lacking of submissions with the intermittent of the internet connectivity and the availability of technological resources. Most of the respondents in home mode used smart phones to accomplish their worksheets at the Edmodo and to attend their online classes. Previous studies likewise stressed the same issues pertaining to internet connectivity and availability of technological resources. Alamazova et al. (2020) mentioned that Russian higher education faced a great challenged because of the lack of computer literacy level of the teachers and the accessibility of electronic environment and support. Goncalves (2020) affirmed that the preparedness of Portugal education about distance learning was immature because the Minister of Education overlooked the numbers of the students without internet connection. This issue was similar in the scenarios of the Sri Lankan universities (Habaragoda, 2020). Karademir et al. (2020) criticized that Turkey's readiness to distance education was premature because of its inaccessibility to students who cannot afford to attend online learning. Hence, the issue encountered by MCC was likewise encountered by some higher educational institutions (HEI's).

Similarly, Table 1 revealed that the total numbers of the students who obtained incomplete grades, were only $39(12.58 \%)$ of the 310 students. The percentage of the incomplete grades was seemed not that critical or censorious but this small percentage should be addressed to assure the quality of education at the MCC. This finding can be attributed to the issue in internet connectivity and the unavailability of technological resources as well as the readiness of the students on the remote or distance learning (Habaragoda, 2020; Goncalves, 2020). Moreover, this finding can be also associated to team teaching strategy which created confusion to students during the semester.

Table 1. Frequency and percentage of complete submission (CS), lacking in submission (LS), no submission (NS) of worksheet and incomplete grade (INC) $(\mathrm{N}=310)$

\begin{tabular}{|c|c|c|c|c|c|}
\hline \multirow{2}{*}{ Mode of Learning } & \multicolumn{3}{|c|}{ Frequency and Percentage } & N \\
\cline { 2 - 6 } & CS & LS & NS & INC & \\
\hline Home & $114(49.56 \%)$ & $108(46.95 \%)$ & $8(3.48 \%)$ & $24(10.43 \%)$ & 230 \\
\hline Hub & $26(32.50 \%)$ & $49(61.25 \%)$ & $5(6.25 \%)$ & $15(18.75 \%)$ & 80 \\
\hline
\end{tabular}

In Table 2, the data revealed that there were significant differences on the mean semestral grades of the students. The students who were in the Home mode of learning obtained a weighted mean of 89.3825 while the students who were in the Hub mode of learning obtained a weighted mean of 85.9605. The obtained $t$ Stat (3.3488) was greater than the $t$ Critical tv (1.9828), which indicated the significant differences. This implied that semestral grades of the students on the Home and Hub mode of learning are statistically different. This finding was affirmed by the obtained p-value 
International Journal of Entrepreneurship, Business and Creative Economy (IJEBCE), Vol. 1 (2), 54-64 Comparison of Hub and Home Mode Learning: An Action Research from Philippines

Arnel G. Perez

(0.0011) which was less than the significant level $(0.05)$ which indicated significant differences. Viz., the finding revealed that the students in the Home mode of learning surpassed the performance of the students who were in the Hub mode of learning. Likewise, the finding indicated that synchronous or online learning (Home mode) was more effective than the asynchronous or offline learning/modular (Hub mode). The students who were into home mode of learning can verify and clarify about the worksheets or activities during the synchronous or online class meeting. Hence, students who were in home mode of learning performed well with their worksheets because of the online discussions. Whereas, students who were in hub mode of learning (modular type), they rely only on the modules and on the link attached in the module.

Table 2. Mean difference between the Home mode and Hub mode ( $\mathrm{N}=296)$

\begin{tabular}{|c|c|c|c|c|c|c|}
\hline \multirow{2}{*}{ Mode } & \multirow{2}{*}{$\mathrm{N}$} & \multirow{2}{*}{ Mean } & \multirow{2}{*}{$\mathrm{df}$} & \multicolumn{3}{|c|}{$\mathrm{t}-$ Value } \\
\cline { 5 - 7 } & & & & tStat & tCritical tv & $\mathrm{P}(\mathrm{T}<=\mathrm{t})$ two-tail \\
\hline Home & 228 & 89.38 & \multirow{2}{*}{105} & 3.35 & 1.9828 & $0.0011^{*}$ \\
\hline Hub & 68 & 85.96 & & & & \multirow{2}{*}{0.9628} \\
\hline
\end{tabular}

As observed, the finding affirmed that there were significant differences on the semestral grades of the students who were into Home and Hub mode of learning. Similarly, the finding revealed that the semestral grades of the students who were in the Home mode of learning were better than the semestral grades of the students who were in the Hub mode of learning. This assumed that the online discussion contributed to the academic performance of the students who were into Home mode of learning. Ergo, this assumed that teacher's interventions in the learning process influenced students' academic performance, even both the students as well as the teachers were still in the period of adjustment with the new paradigm or mode of learning.

Similarly, the finding assumed that teacher's methods of teaching such as the utilization of power point presentation during the online discussion, recording the online discussion for the broadcast purposes, posting the links of the recorded online discussion at the Edmodo, conducting quiz before the next online discussion, and frequent posting of reminders at the Edmodo influenced the academic performance of the students who were in Home mode of learning.

\section{Implication of the action research}

Recent studies underscored the different actions of the Higher Educational Institutions (HEI's) all over the world in securing the health of the students as well as the academic personnel, and likewise in mitigating the spread of coronavirus or COVID-19. Most of HEI's closed the schools in March 2020 and shifted their paradigm from face-to-face to distance or remote learning (Almazova et al., 2020; Balakrishnan, 2020; Bozkurt et al., 2020; CHED, 2020; Ghazi-Saidi et al., 2020; Goncalves, 2020; Habaragoda, 2020; Karademir et al., 2020; Mukherjee \& Hasan, 2020; \& Refaat El Said, 2020).

However, some HEI's specific to the countries like Indonesia, Malaysia, Singapore and Thailand (Balakrishnan, 2020); China, Japan, India, Russia, Saudi Arabia, South Korea, Philippines (Asia), Algeria, Egypt, Kenya, Ghana, Namibia, South Africa, Uganda (Africa); France, Greece, Republic of Ireland, Romania, Spain, Sweden, Netherlands, Turkey, United Kingdom (Europe); Canada, United States (North America); Argentina, Brazil, Mexico, Peru, Uruguay (South America) and Australia (Bozkurt et al., 2020); Sri Lanka (Habaragoda, 2020); and Portugal (Goncalves, 2020) utilized synchronous or online learning to continue the education of the students. Hence, previous researches stressed some concerns about the immediate actions of the HEI's which included the readiness of the academic staff and students in online learning; computer literacy level and electronic environment and support (Almazova et al, 2020); poor internet connectivity and weak IT skills (Refaat El Said, 2020); lack of access to electricity and poor IT infrastructure in the remote areas (Habaragoda, 2020); huge numbers of the students without internet connection (Bozkurt et 
International Journal of Entrepreneurship, Business and Creative Economy (IJEBCE), Vol. 1 (2), 54-64 Comparison of Hub and Home Mode Learning: An Action Research from Philippines

Arnel G. Perez

al., 2020; Karademir, 2020; Goncalves, 2020); and infrastructural and psychological issues (Karademir, 2020).

As previously mentioned, some HEI's overlooked the effects of online learning to the students who lived in the remote areas and had no access to electricity and internet. Hence, some HEI's failed to comply on the UNESCO Sustainable Development Goal 4 (SDG 4) of the 2030 Agenda that aims to "ensure inclusive and equitable quality education and promote lifelong learning opportunities for all" (UNESCO, 2017) and the former "Education for All" or EFA 2015 (UNESCO, 2013).

The Mabalacat City College (MCC) as one of the HEI's in the Philippines resolved this concern through its innovative flexible learning. In the flexible learning of MCC, the students were given options to choose between the Hub mode (modular type) and Home mode (online class). Its immediate action was to place Hubs on the different barangays of Mabalacat City. In the Hub mode, the students accomplish their academic requirements (worksheets) by claiming their modules, as well as the worksheets, from the respective Hubs of the barangays, where they would also return them. Whereas, in the Home mode of learning, the students secure and submit their worksheets at the Edmodo and they attend their online discussion at least three hours per subject in a week. Hence, MCC's flexible learning was both accessible and inclusive which complied to SGD 4 (UNESCO, 2017) and the former EFA 2015 (UNESCO, 203), and universal goal of education, "No child left behind".

Moreover, the finding in this action research confirmed the advantage of the Home mode over the Hub mode of learning, and found out that both mode of learning had concern withcomplete submission, lacking in submission, no submission of worksheet and incomplete grade of the students. Hence, to address these concerns, the researcher suggests the following actions: 1) All Hubs in the respective barangay should have someone who monitor and follow-up the claiming and submission of the worksheets; 2) The Hubs in respective barangay instruct the students to have back-up with their worksheets (photos of accomplished worksheets); 3) All worksheets must be sorted upon returning to the respective institutes and make a list of the students who submitted their worksheets; and 4) For the Home mode, the Field of study head (FOSH) should monitor the online classes of the instructors, and require the instructors to monitor the compliance of the students with the worksheets, attendance on online discussion, quizzes and others.

\section{CONCLUSION}

The immediate action of MCC to mitigate the spread of coronavirus was to implement flexible learning which was both accessible and inclusive. Its mode of learning became flexible because the students were given option to choose between the Hub mode (asynchronous or modular type) and Home mode (synchronous or online class). Its flexible learning complied to UNESCO Sustainable Development Goal 4 (SDG 4) of the 2030 Agenda that aims to "ensure inclusive and equitable quality education and promote lifelong learning opportunities for all" (UNESCO, 2017). Likewise, its flexible learning was compliant to CMO No. 4, Series of 2020, which required all public and private Higher Education Institutions (HEIs) in the Philippines to utilize flexible learning that involved combination of digital and non-digital technology which aimed to ensure the continuity of inclusive and accessible education (Commission on Higher Education, 2020). Hence, MCC's flexible learning attained the universal goal of education, the "No child left behind".

This action research determined the significant differences of MCC's flexible learning between the Hub and Home mode of learning. The finding revealed that the students who were into Home mode, surpassed the performance of the students who were into Hub mode in terms of the following: complete submission; lacking in submission; no submission of worksheets and incomplete grades. Similarly, the finding revealed that the semestral grades of the students who were in the Home mode of learning were better than the semestral grades of the students who are in the Hub mode of learning. This assumed that the online discussion contributed to the academic performance of the students who were into Home mode of learning. 
Moreover, the advantage of the students who were into Home mode of learning over the students who were into Hub mode of learning can be attributed to teacher's methods of teaching such as the utilization of power point presentation during the online discussion, recording the online discussion for the broadcast purposes, posting the links of the recorded online discussion at the Edmodo, conducting quiz before the next online discussion, and frequent posting of reminders at the Edmodo. Hence, the finding affirmed that teacher's intervention can influence students' performance.

In the end, the essence of this action research was not about the advantage of the Home mode to the Hub mode of learning but on how MCC resolved the issues on the right to education especially in the time of adversity due to the COVID-19 pandemic. Moreover, the findings in this action research will serve as bases to address the needs in the innovative flexible learning of MCC.

\section{ACKNOWLEDGEMENT}

The author would like to acknowledge the efforts of the students who are the respondents in this study.

\section{CONFLICT OF INTEREST}

The authors of this article hereby declares that there is no conflict of interests whatsoever with respect to the publication of this paper

\section{ETHICAL APPROVAL}

Data in this action research were the grades of the students who took the course, The Life and Works of Rizal, and their records in the submission of worksheets. Variables such as name, age, gender, ethnicity, religion, economic status, and other variables related to the profile of the students were not part of this action research. The data such grades of the students are technically owned by MCC which has the right to utilize them for research. In like manner, the class record of the students are personally owned by the instructor who is the researcher in this study.

\section{REFERENCES}

Almazova, N., Krylova, E., Odinokaya, M. \& Rubtsova, A. (2020). Challenges and opportunities for Russian Higher Education amid COVID-19: Teachers' perspectives. Education Science. http://dx.doi.org/10.3390/educsci10120368

Balakrishnan, P. (2020). Education in the age of COVID-19: Educational responses from four Southeast Asian countries. International Studies in Educational Administration, Vol.48(3). http://web.a.ebscohost.com/ehost/pdfviewer/pdfviewer?vid=14\&sid=392c76a7-07514ec1-9900-467c69a537cc\%40sdc-v-sessmgr02

Bozkurt, A., Jung, I., Xiao, J., Vladimirschi, V., Schuwer, R., Egorov, G., Lambert, S., Al-Freih, M., Pete, J., Olcott, Jr., D., Rodes, V., Aranciaga, I., Bali, M., Alvarez, Jr., A., Roberts, J., Pazurek, A., Raffaghelli, J., Panagiotou, N., de Coëtlogon, P., Sadik Shahadu, S. et al. (2020). A global outlook to the interruption of education due to COVID-19 pandemic: Navigating in a time of uncertainty and crisis. Asian Journal of Distance Education, Vol. 15(1), p. 1-126. https://eric.ed.gov/?id=EJ1290039

Commission on Higher Education (2020). Guideline on the implementation of flexible learning, CMO No. 4, Series of 2020. https://ched.gov.ph/wp-content/uploads/CMO-No.-4-s.-2020Guidelines-on- the-Implementation-of-Flexible-Learning.pdf

Congress of the Philippines (2020 September 11). Republic Act No. 11494 or "Bayanihan to Recover As One Act". Official Gazette of the Philippine Government. https://www.officialgazette.gov.ph/downloads/2020/09sep/20200911-RA-11494-RRD.pdf 
International Journal of Entrepreneurship, Business and Creative Economy (IJEBCE), Vol. 1 (2), 54-64 Comparison of Hub and Home Mode Learning: An Action Research from Philippines

Arnel G. Perez

DepEd Commons (2020). DepEd Commons Framework. https://commons.deped.gov.ph/ Diplomat Risk Intelligence (2020 April 14). COVID-19 in Asia: A Country-by-country guide. The good, the bad, and the ugly of the coronavirus fallout for each government in East, Southeast, South, and Central Asia. https://thediplomat.com/2020/04/covid-19-in-asia-a-country-by-countryguide/

Goncalves, S.P. (2020). Education in the context of the pandemic: A Look at the case of Portugal. Revisita Romaneasca pentru Educatie Multidimensionala, 12(1Sup2), 78-85. https://doi.org/10.18662/rrem/12.1sup2/249

Harabaragoda, B.S. (2020). Challenges of implementing online teaching in universities during COVID-19 global pandemic: A Developing country's perspective. International Journal of management, Accounting and Economics, Vol.7(11). http://web.a.ebscohost.com/ehost/pdfviewer/pdfviewer?vid=9\&sid=392c76a7 0751-4ec19900-467c69a537cc\%40sdc-v-sessmgr02

Hur, S. \& Fenuwine M. (2020). Lessons on the economics of pandemics from recent research.

Economic Commentary. http://doi:10.26509/frbc-ec-202011

Karademir, A., Saatcioglu, O. \& Yaman, F. (2020). Challenges of higher education institutions against COVID-19: The case of Turkey. Journal of Pedagogical Research, Vol. 4(4). http://dx.doi.org/10.33902/JPR.2020063574 Kothari, C.R. (2004). Research Methods and Techniques, 2nd Revised Edition. New Delhi: New Age International. $\quad$ eBook Academic Collection.

http://web.b.ebscohost.com/ehost/ebookviewer/ebook/ZTAwMHh3d19fMjc3NDY1X19BT g2?sid=7b4

5a593-2389-4d34-a6736f30d5cb9305@sessionmgr101\&vid=3\&format=EB\&rid=2

Kouser, S., Kausar, S., \& Ghani, M. (2020). COVID-19 lockdown: current situation and challenges facing in Pakistan during lockdown. Biomedica, Vol.36, p. 138-144. Retrieved from http://web.a.ebscohost.com/ehost/detail/detail?vid=6\&sid=5031cf65-3123-4469-9695-

Litshani, N.F., Mashau, T.S., Mohale, A.B., Moyo, H., Mudau, T.J. \& Sebopetsa, NS. (2020). The impact of COVID-19 pandemic on the implementation of curriculum recovery plan in Mopani West District, Limpopo Province. Gender \& Behavior, Vol. 18(4). http://web.b.ebscohost.com/ehost/pdfviewer/pdfviewer?vid=3\&sid=f9432d9b-b3ca-4d0faa64- bc068ad067d8\%40pdc-v-sessmgr01

Magsambol, B. $\quad(2020$ July 22). Fast Facts: CHED's flexible learning. https://www.rappler.com/newsbreak/iq/things-to-know-ched-flexible-learning

Mukherjee, D. \& Hasan, K. (2020). Challenges in learning continuity during the COVID-19 Pandemic: A Methodological and thematic review. South Asian Journal Management, Vol. 27 (3). http://web.b.ebscohost.com/ehost/pdfviewer/pdfviewer?vid=32\&sid=a8f5aae0-b2014459-a6f3- df0a9a050412\%40sessionmgr103

Omnibus Guidelines on the Implementation of Community Quarantine in the Philippines with Amendments as of January 21, 2021. https://www.officialgazette.gov.ph/downloads/2021/01jan/20210121-IATF-OMNIBUSGUIDELINES- RRD.pdf

Ornell, F., Schuch, J.B., Sordi, A.O., \& Kessler, FH, P. (2020). Pandemic fear and COVID-19: Mental health burden and strategies. Brazilian Journal of Psychiatry, Vol.42(3). http://doi:10.1590/1516-446- 2020-0008 
International Journal of Entrepreneurship, Business and Creative Economy (IJEBCE), Vol. 1 (2), 54-64 Comparison of Hub and Home Mode Learning: An Action Research from Philippines

Arnel G. Perez

Refaat El Said, G. (2020). How did the COVID-19 pandemic affect higher educational learning experience? An Empirical investigation of learners' academic performance at a university in a developing country. Advances in Human-Computer Interaction. https://doi.org/10.1155/2021/6649524

Republic of the Philippines Department of Health. (2021). COVID-19 Inter-Agency Task Force for the Management of Emerging Infectious Diseases Resolutions. https://doh.gov.ph/COVID19/IATF- Resolutions

UNESCO (2013). Education for All. National EFA 2015 Reviews.

Guidelines.http://www.unesco.org/new/fileadmin/MULTIMEDIA/FIELD/Santiago/pdf/gui delinesnationalefa201 5reviewsenglish19062013.pdf

UNESCO (2017). UNESCO moving forward the 2030 Agenda for Sustainable development. https://en.unesco.org/creativity/files/unesco-moving-forward-2030-agenda-sustainable

World Health Organization (2020 March 11). WHO Director-General's opening remarks at the media briefing on COVID-19-11 March 2020. https://www.who.int/directorgeneral/speeches/detail/who-director-general-s-opening-remarks-at-the-media-briefingon-covid-19---11-march-2020

\section{Software Application}

$\begin{array}{llllll}\text { Microsoft } & \text { Excel for } & \text { Mac software } & \text { version } 16.40 & \text { (2019). Microsoft }\end{array}$ Corporation. https://support.office.com/legal?llcc=enus\&aid=Office_Mac_Use_Terms_2018_en-us.htm 